\title{
Setting boundaries: Environmental and spatial effects on Odonata larvae distribution (Insecta)
}

\author{
THIAGO P. MENDES ${ }^{1,3}$, HELENA S. R. CABETTE ${ }^{2}$ and LEANDRO JUEN ${ }^{3}$ \\ ${ }^{1}$ Programa de Pós-graduação em Ecologia Aquática e Pesca, Instituto de Ciências Biológicas, \\ Universidade Federal do Pará, Rua Augusto Correia, 1, Bairro Guamá, 66075-110 Belém, PA, Brasil \\ ${ }^{2}$ Laboratório de Entomologia, Departamento de Ciências Biológicas, Universidade do Estado de Mato Grosso, \\ BR 158, Km 148, Caixa Postal 08, 78690-000 Nova Xavantina, MT, Brasil \\ ${ }^{3}$ Laboratório de Ecologia e Conservação, Instituto de Ciências Biológicas, Universidade Federal do Pará/UFPA, \\ Rua Augusto Correia, 1, Bairro Guamá, 66075-110 Belém, PA, Brasil
}

Manuscript received on November 25, 2013; accepted for publication on September 20, 2014

\begin{abstract}
Environmental characteristics and spatial distances between sites have been used to explain species distribution in the environment, through Neutral (space) and Niche theory (environment) predictions. We evaluated the effects of spatial and environmental factors on Odonata larvae distribution along the Suiá-Missú River Basin, state of Mato Grosso. We tested the hypotheses that (1) the environment is the main factor structuring the community due to its ecophysiological requirements; and (2) the pattern, if present, is clearer for Zygoptera. Samples were made in 12 sites on the Suiá-Missú River Basin in three seasons (2007/2008), with a total of 1.382 Odonata larvae, comprising 10 families, 51 genera and 100 morphospecies. The Anisoptera were more abundant than Zygoptera, comprising $81 \%$ of all specimens. The environment affected Zygoptera $(\mathrm{R}=0.291 ; \mathrm{p}=0.007)$ and was the main factor structuring the assembly. Thus, Niche theory was confirmed. The absence of this effect on Anisoptera may be due to the ecophysiological adaptations that enable it to occupy different habitats. Zygoptera larvae are indicators of changes in habitat structure. The effects of environmental variables on larvae ecology emphasize the strong relationship between these organisms and environmental integrity.
\end{abstract}

Key words: Anisoptera, Zygoptera, neutral theory, niche theory, transition Cerrado-Amazon.

\section{INTRODUCTION}

Habitat structural complexity is composed of environmental and spatial factors which act as filters for migration and niche colonization processes (Poff 1997). For a long time, ecological researchers have relied on theories to discuss how composition and species richness may be influenced by such effects and its consequent

Corresponding author: Thiago Pereira Mendes

E-mail: thiagomendes.bio@gmail.com restrictions (Case and Gilpin 1974, Chesson and Warner 1981, Pontin 1982, Ricklefs 1987). Niche and neutral theory approaches have been involved in such debates. The Unified Neutral Theory of Biodiversity and Biogeography (NTBB) is built from the perspective that assemblies are formed through dispersal and species extinction processes. Therefore, diversity would be maintained only by ecological stochasticity, in local and regional scales (Hubbell 2001). 
According to the neutral theory, all species have ecological equivalents and the main structuring agent of faunal similarity in an ecological time scale, would be dispersal measured by geographic distance between the communities (Chave 2004). The most obvious consequence is that closer sites would share more species (Hubbell 2001, Scarano and Dias 2004).

Niche theory, on the other hand, argues that the main factors affecting species distribution are environmental characteristics, once each species would have a set of biotic and abiotic conditions setting the limits in which species can persist (Case and Gilpin 1974). Sites with similar environmental characteristics would have an identical composition. Ecological communities are assemblages of species with a limited number of members coexisting in equilibrium, undergoing strict partitioning of niche and limiting resources. Thus, an increase in habitat structural complexity (environmental heterogeneity) and in the partitioning of different niches and micro-climates, can lead to balance through species coexistence (speciation or specialization), minimizing the effects of competitive exclusion (Taniguchi and Tokeshi 2004, Thomaz et al. 2008, Jankowski et al. 2009).

Environmental and spatial effects on the distribution of organisms depend on species sensitivity to environmental heterogeneity and dispersal ability. The Odonata subordersAnisoptera and Zygoptera have disparate morphological and ecophysiological characteristics. The Anisoptera are usually larger and have greater dispersal ability, while the Zygoptera are overall smaller and have more limited dispersal (Corbet 1999). Still, such attributes may have interspecific variations (Heckman 2006, Córdoba-Aguilar 2008). According to Heiser and Schmitt (2010) this difference in dispersal ability is related to the dependence on temperature, climate and the environment. The temperature, climate and the environment are the main regulators of dispersal.
Zygoptera would be more affected by environmental characteristics and space than Anisoptera, for being more habitat dependent (Corbet 1999) and having less dispersal ability. Such effects are not as significant for Anisoptera, which have greater dispersal ability. Space would not be a barrier for these organisms, and sites with environmental conditions different from what would be supported by its niche breadth, would act as environmental filters. This study aimed to evaluate to what extent community structure and Odonata larvae distribution are influenced by distance between the sites (Neutral theory) and environmental variables (Niche theory). We tested the following hypotheses: (1) the environment is the main factor structuring the community due to the sensibility and ecological demands of the Odonata order and its infraorder; (2) space has little structuring effects on the community, once sites of the Suiá-Missú River Basin area are connected. However, all clade elements are not expected to uniformly respond to these effects (Hayes and Sewlal 2004) due to the existence of differences in dispersal ability and in ecophysiological requirements among species of the studied suborders. If environmental and geographic distances are in fact responsible for structuring the Odonata community, we expect the effects to be clearer for the suborder Zygoptera.

\section{MATERIALS AND METHODS}

The Odonata larvae were sampled on 12 sites along the Suiá-Missú River Basin, in eastern Mato Grosso, at the towns of Querência, Ribeirão Cascalheira and Canarana. Distance between sites ranged from $130.69 \mathrm{~km}$ (closest sites) to 445.45 $\mathrm{km}$ (most distant sites). Sites were located from latitudes $11^{\circ} 49^{\prime}$ to $13^{\circ} 15^{\prime} \mathrm{S}$ and meridians $51^{\circ} 53^{\prime}$ to $52^{\circ} 21^{\prime} \mathrm{W}$. The region has a tropical climate, subtype Savannah (Aw) with micro-regions of Monsoons (Am) and Tropical Rainy (A) subtypes, according to the Köppen classification. The dry season occurs 
from May to October, and the rainy season from November to April. Average precipitation is 1,370 $\mathrm{mm}$ and temperature varied from $32.7^{\circ} \mathrm{C}$ to 17.0 ${ }^{\circ} \mathrm{C}$ (Ratter et al. 1978).

The samples were collected in the River Basin Suiá-miçú in three seasons: dry season (September/2007), beginning of the rainy season (December/2007) and draw down period (May/2008), with the purpose of sampling a greater environmental variation. The following water bodies were sampled: Sucuri Stream, Brejão Stream, Darro River, Suiazinho River, Suiá-Missú River (sites 1, 2 and 3), Piabanha River, Lúcio Stream, Betis River (Forest), Betis River (dam), and Brejo Transition Stream.

The Odonata larvae were sampled on the marginal substrates (roots, leaves, small stones, gravel, sand etc.), with a hand sieve of $18 \mathrm{~cm}$ diameter and mesh opening of $250 \mu \mathrm{m}$, in 100 meter transects. Transects were delimited on the right bank of the water bodies, which were subdivided into 20 segments measuring 5 meter each (modified from Ferreira-Peruquetti and De Marco Jr 2002). The substrate present on the river banks (roots, leaves, small stones, gravel, sand etc.) was sampled in each segment and the specimens were separated and fixed in $85 \%$ ethanol.

The samples were identified using the identification keys of Needham et al. (2000), Heckman (2006) and Costa et al. (2004), and stored at the "James Alexander Ratter" Zoobotanical collection at the State University of Mato Grosso (Universidade Estadual do Mato GrossoUNEMAT), campus Nova Xavantina (CZNX).

Analyses were carried out first with the Odonata data. It was later carried out separately for each of the two suborders, comprising all three sampling campaigns. Separated, in order to evaluate the spatial and environmental effects in each sampling procedure. The abundance data underwent a logarithmic transformation $\left[\log _{10}(x+1)\right]$ to minimize the effects of outliers.
A Partial Redundancy Analysis (RDAp) (Legendre and Legendre 1998) was used to evaluate the hypothesis that environmental variables would be more important in structuring the Odonata larvae than spatial variables. The response variables used were density and occurrence matrices (presence/absence) and the explanatory variables were the sets of standardized environmental variables (Environment). The matrix of spatial filters was created with the analysis of Principal Coordinates of Neighbor Matrices (PCNM) (Borcard and Legendre 2002, Borcard et al. 2004, Diniz-Filho and Bini 2005, Dray et al. 2006, Griffith and Peres-Neto, 2006), used to create a matrix of linear distance between the sampling sites. The eigenvectors with coefficients greater than $0.1 \mathrm{R}$ Moran were included in the spatial predictor matrix. This analysis was performed using the Spatial Analysis in Macroecology v. 4.0 software (SAM, Rangel et al. 2010). The RDAp has four explanation fractions: [a] "X/E", variation attributed solely to the environmental variables; $[\mathrm{b}]$ " $\mathrm{E} / \mathrm{X}$ ", variation attributed solely to the spatial variables; $[\mathrm{c}]$ "X+E", the variation explained by space and environment (variability in community structure explained by spatially structured environmental variation); [d] residual variation (variation not explained by the previous fractions). Test significance was assessed through a permutation test with 999 randomizations (Peres-Neto et al. 2006). All tests were carried out in the Software R, using the package VEGAN, and function Varpart (R Software, www.r-project.org) (R Development Core Team 2010).

\section{RESULTS}

A total of 1,384 Odonata individuals were sampled. The suborder Anisoptera was the most abundant with 1,127 individuals, comprising four families (Aeshnidae, $n=3$; Cordullidae, $n=23$; Gomphidae, $\mathrm{n}=363$; and Libellulidae, $\mathrm{n}=738$ ), 41 genera and 80 species and/or morphospecies (msp). A total of 257 individuals of the suborder Zygoptera were sampled, comprising six families (Calopterygidae, 
$\mathrm{n}=12 ;$ Dicteriadidae, $\mathrm{n}=2 ;$ Megapodagrionidae, $\mathrm{n}=15$; Polythoridae, $\mathrm{n}=2$; and Coenagrionidae/ Protoneuridae, $\mathrm{n}=226$ ), 16 genera and $20 \mathrm{msp}$, amounting 100 msp for the Suiá-Missú River Basin.

The scores of the PCNM derived matrix of geographical coordinates were used to represent the spatial variables in the statistical analysis. According to the described criteria, four spatial filters were selected. Thus, the RDAp results, regarding all campaigns indicated that only the environment $(\mathrm{X} / \mathrm{E})$ had significant effect on Odonata $\left(\mathrm{R}^{2}=0.190\right.$; $\mathrm{p}=0.001)$ and Zygoptera $\left(\mathrm{R}^{2}=0.291 ; \mathrm{p}=0.007\right)$
(Table I). It did not affect Anisoptera. The spatial predictors $(\mathrm{E} / \mathrm{X})$ did not have significant effects on any of the analyzed taxonomic resolutions (Odonata or Zygoptera and Anisoptera). Only environmental predictors affected the order level $\left(\mathrm{R}^{2}=0.263 ; \mathrm{p}=\right.$ $0.041)$ and the Zygoptera community $\left(\mathrm{R}^{2}=0.417\right.$ $\mathrm{p}=0.014)$ (Table II) during the rainy season (E-C). During the dry season (E-S), the environment had significant effects only on the Zygoptera suborder $\left(\mathrm{R}^{2}=0.379 ; \mathrm{p}=0.039\right)$. There was no significant effect of any of the predicting variables on the draw down period (Table II).

TABLE I

Sites sampled and their acronyms, geographic coordinates, and species richness for the sites sampled and the suborders Anisoptera and Zygoptera at the Suiá-Missú River Basin, MT.

\begin{tabular}{cccccccc}
\hline Sites & Acronyms & \multicolumn{2}{c}{ Geographic coordinates } & $\begin{array}{c}\text { Observed species } \\
\text { richness }\end{array}$ & \multicolumn{2}{c}{$\begin{array}{c}\text { Estimated richness } \\
\text { (mean } \pm \text { standard deviation) }\end{array}$} \\
\hline & & S & W & Anisoptera & Zygoptera & Anisoptera & Zygoptera \\
\hline C. Brejão & CRBJ & $12^{\circ} 38^{\prime} 32,3^{\prime \prime}$ & $51^{\circ} 53^{\prime} 20,6^{\prime \prime}$ & 19 & 12 & $(26,87 \pm 2,61)$ & $(16,93 \pm 2,37)$ \\
C. Lucio & CRL & $13^{\circ} 05^{\prime} 34,5^{\prime \prime}$ & $52^{\circ} 15^{\prime} 16,9^{\prime \prime}$ & 17 & 8 & $(27,82 \pm 3,57)$ & $(10,95 \pm 2,18)$ \\
C. Sucuri & CRSRI & $11^{\circ} 49^{\prime} 50,7^{\prime \prime}$ & $52^{\circ} 17^{\prime} 02,2^{\prime \prime}$ & 24 & 5 & $(33,83 \pm 2,86)$ & $(1,98 \pm 0,98)$ \\
C. Trans-Brejo & CRTB & $13^{\circ} 03^{\prime} 35,6^{\prime \prime}$ & $52^{\circ} 12^{\prime} 03,3^{\prime \prime}$ & 32 & 5 & $(39,78 \pm 3,99)$ & $(7,98 \pm 0,98)$ \\
Rio Betis 1 & RIBET1 & $12^{\circ} 22^{\prime} 28,7^{\prime \prime}$ & $52^{\circ} 13^{\prime} 23,1^{\prime \prime}$ & 21 & 2 & $(31,82 \pm 3,29)$ & $(2,98 \pm 0,98)$ \\
Rio Betis 2 & RIBET2 & $12^{\circ} 22^{\prime} 27,5^{\prime \prime}$ & $52^{\circ} 13^{\prime} 19,0^{\prime \prime}$ & 33 & 4 & $(51,68 \pm 4,96)$ & $(5,98 \pm 0,98)$ \\
Rio Darro & RID & $12^{\circ} 21^{\prime} 12,3^{\prime \prime}$ & $52^{\circ} 21^{\prime} 27,4^{\prime \prime}$ & 18 & 8 & $(25,87 \pm 2,96)$ & $(9,95 \pm 1,67)$ \\
Rio Piabanha & RIPB & $13^{\circ} 15^{\prime} 34,4^{\prime \prime}$ & $52^{\circ} 09^{\prime} 00,5^{\prime \prime}$ & 23 & 6 & $(35,78 \pm 4,45)$ & $(8,95 \pm 1,67)$ \\
Rio Suiá1 & RISU1 & $13^{\circ} 15^{\prime} 45,5^{\prime \prime}$ & $52^{\circ} 02^{\prime} 50,9^{\prime \prime}$ & 16 & 3 & $(28,78 \pm 3,99)$ & $(3,98 \pm 0,98)$ \\
Rio Suiá2 & RISU2 & $13^{\circ} 15^{\prime} 24,3^{\prime \prime}$ & $52^{\circ} 08^{\prime} 44,5^{\prime \prime}$ & 11 & 2 & $(16,9 \pm 2,7)$ & $(2,98 \pm 0,98)$ \\
Rio Suiá3 & RISU3 & $11^{\circ} 50^{\prime} 17,8^{\prime \prime}$ & $52^{\circ} 15^{\prime} 07,5^{\prime \prime}$ & 31 & 7 & $(47,72 \pm 4,45)$ & $(13,9 \pm 2,3)$ \\
Rio Suiazinho & RISUZ & $12^{\circ} 38^{\prime} 33,4^{\prime \prime}$ & $51^{\circ} 56^{\prime} 50,7^{\prime \prime}$ & 27 & 8 & $(39,78 \pm 3,46)$ & $(10,95 \pm 1,67)$ \\
\hline
\end{tabular}

Significance level $(\mathrm{p}<0.05)$.

The main results obtained in the variance partitioning analyses indicated that environmental predictors are more important in explaining the variation present in the Odonata community, than spatial predictors. This effect is clearer during the rainy season. However, this result was only for the order level and for the suborder Zygoptera, once none of the tests indicated a significant relationship for Anisoptera.

\section{DISCUSSION}

The Odonata order has many variations in habitats according to its biological requirements. An example of habitats variation is the thermoregulatory process that varies according to body size of the specimen and would be directly related to habitat selection (May 1976). Chovanec and Waringer (2001) assert the importance of Odonata as bioindicators at different spatial scales, mainly due to their close 
TABLE II

Results of the community structure and distribution variation partitioning (RDA). The letter $\mathrm{V}$ represents the variables. The ratio $\mathrm{X} / \mathrm{E}$ corresponds solely to the environmental effect, $E / X$ dolely to the spatial effect, $\mathrm{X}+\mathrm{E}$ the interaction effects, and [D] the residuals $(\mathrm{E}-\mathrm{S}=$ dry season; $\mathrm{E}-\mathrm{C}=$ rainy season; $\mathrm{E}-\mathrm{V}=$ draw down period).

\begin{tabular}{cccccccc}
\hline \multirow{2}{*}{ Samples } & \multicolumn{3}{c}{ Odonata Order } & \multicolumn{2}{c}{ Anisoptera Suborder } & \multicolumn{2}{c}{ Zygoptera Suborder } \\
& $\boldsymbol{V}$ & $\boldsymbol{R}^{\mathbf{2}}$ & $\boldsymbol{p}$ & $\boldsymbol{R}^{\mathbf{2}}$ & $\boldsymbol{p}$ & $\boldsymbol{R}^{\mathbf{2}}$ & $\boldsymbol{P}$ \\
\hline \multirow{5}{*}{ All seasons } & $\mathrm{X} / \mathrm{E}$ & 0.190 & 0.001 & 0.024 & 0.549 & 0.291 & 0.007 \\
& $\mathrm{E} / \mathrm{X}$ & 0.023 & 0.171 & 0.006 & 0.470 & 0.050 & 0.078 \\
& $\mathrm{X}+\mathrm{E}$ & 0.039 & & 0.055 & & 0.016 & \\
& $\mathrm{D}$ & 0.748 & & 0.925 & & 0.643 & \\
& $\mathrm{X} / \mathrm{E}$ & 0.220 & 0.237 & 0.134 & 0.298 & 0.348 & 0.247 \\
& $\mathrm{E} / \mathrm{X}$ & 0.105 & 0.443 & 0.110 & 0.454 & 0.165 & 0.411 \\
& $\mathrm{X}+\mathrm{E}$ & 0.040 & & 0.059 & & 0.014 & \\
& $\mathrm{D}$ & 0.635 & & 0.697 & & 0.473 & \\
& $\mathrm{X} / \mathrm{E}$ & 0.301 & 0.669 & 0.231 & 0.110 & 0.379 & 0.039 \\
& $\mathrm{E} / \mathrm{X}$ & 0.151 & 0.380 & 0.103 & 0.450 & 0.225 & 0.208 \\
& $\mathrm{X}+\mathrm{E}$ & 0.059 & & 0.105 & & 0.121 & \\
& $\mathrm{D}$ & 0.489 & & 0.561 & & 0.275 & \\
& $\mathrm{X} / \mathrm{E}$ & 0.263 & 0.041 & 0.232 & 0.072 & 0.417 & 0.014 \\
& $\mathrm{E} / \mathrm{X}$ & 0.139 & 0.266 & 0.13 & 0.277 & 0.199 & 0.127 \\
& $\mathrm{X}+\mathrm{E}$ & 0.194 & & 0.198 & & 0.231 & \\
\hline
\end{tabular}

Significance level $(\mathrm{p}<0.05)$.

dependence on local environmental conditions in habitat selection. Odonata larvae distribution was affected by the environment, and this pattern is related mainly to the suborder Zygoptera. Species from this suborder were more sensitive to impacts and have lower dispersal abilities, when compared to Anisoptera. Furthermore, the Zygoptera have habitat specific ecological and behavioral requirements, which may limit their spatial distribution (May 1976, Corbet 1999, De Marco and Vianna 2005, Juen and De Marco 2012). In general, adult Zygoptera individuals may be thermal conformers and/or heliothermic. Larger individuals (e.g., Hetaerina) are generally heliothermic, and consequently, totally dependent on solar irradiation. Thermal conformers (e.g., Epipleoneura, Oxyagrion and Telebasis, Zygoptera) have high thermal conductance associated to body size. Body temperature will vary according to the environment due to heat transfer (Heinrich and Casey 1978, May 1991, Heinrich 1993). A close relation is expected between thermal conformers and the environment, once organisms with such characteristics need specific conditions for survival. This will directly influence larvae distribution and occurrence. Another determining factor in larvae distribution is the choice of oviposition sites. It seems to be visually determined by adults (Assis et al. 2004), and after egg hatching the larvae search for the preferred substrate (Conrad et al. 2002).

Many of the Zygoptera species present were restricted, supporting the statement that individuals from this order are regulated by specific environments within the basin (e.g. Heteragrion sp.1, Chalcopteryx sp.1, Heliocharis sp.1 and Acanthagrion sp.1, on CRL, RID and CRBJ, all conserved sites). Thus, these species are potential environmental quality indicators and require greater attention, as they may disappear if these environments change. The Zygoptera have lower dispersal ability and are thus restricted to specific habitats (Corbet 1999). This supports our 
hypothesis that individuals from this suborder respond to environmental requirements. Moreover, most Anisoptera specimens are considered endothermic, and endogenous heat is produced (Corbet 1962, May 1976). Due to its high mobility, which controls the hemolymph circulation (May 1976). The Anisoptera are more tolerant to diverse environmental conditions and are able to reach sites farther from their original region (Hughes et al. 2000, Tscharntke et al. 2002. Sites ranged from preserved to impacted by vegetation loss and cattle stepping. Thus, human activities in preserved areas with open canopy and riparian vegetation, comprising Buriti palms in wetlands, may have induced the low Zygoptera diversity. Still a clear influence of the environmental component structuring this community was found. These landscape changes would increase the number of opportunistic anisopteras (e.g., Diastatops; present on sites CRBJ, CRSI, CRTB, RISU3, RIBET2, RIPB, RISUZ and RID), reducing the degree to which the Anisoptera suborder is structured by the environmental and spatial components.

The lack of response to environmental and spatial factors and the higher Anisoptera species richness may have been influenced by two factors. First, the presence of open areas enables female foraging, once larger bodied insects tend to spend less energy per biomass unit in its maintenance (Peters 1987, Hallgrímsson 2000). Therefore, the Anisoptera are more efficient in extracting energy from low quality resources so that a given amount of energy available in the environment can support a higher biomass of larger species than smaller ones. Thus, these individuals would have broader niches and lower environmental specificity (Corbet 1999). Second, presence of spaces modified by the removal of original forest and landscape replacement with pastures and monocultures makes the environment unsuitable for Zygoptera, but not for Anisoptera, given its high adaptability and dispersal ability (May 1976, De Marco and Latini
1998, Corbet 1999). This confirms our hypotheses that this suborder would not be influenced by geographical and environmental distance.

The abundance of certain species is strongly associated with the success of larval development, with the smaller energy use of adults in choosing and defending territory, and with habitat arrangement (Harvey and Corbet 1985, Thompson 1987, Moore 1987). Thus, these factors may predict the abundance of individuals (De Marco and Vianna 2005, Juen et al. 2007).

The lack of association between environmental variation and Zygoptera during the draw down period may be related to habitat destruction due to water level variations (width and depth) between seasons (dry and rainy seasons), as indicated by Diniz-Filho et al. (1998). Such patterns may also have been caused because some environmental variables have a multicollinearity relationship. Such relationship hinders the evaluation of environmental effects on the community, as observed by Juen and De Marco Jr (2011) regarding depth and width of water bodies.

Relationships between environmental variations and Zygoptera larvae, and not Anisoptera larvae, were observed. The draw down period was an exception for not showing significant results for any of the biological groups (Odonata, Zygoptera or Anisoptera). Thus, our hypothesis that the environment regulates the composition of Zygoptera and not Anisoptera is sustained.

Some species undergo certain speciation that enable them to be more competitive within their ecological niches (Pontin 1982). Thus, although the Anisoptera are generalists, some species were restricted to some environments (e.g. Agriogomphus sp.1 and Brachymesia sp.1 in a small impacted stream; Dasythemis sp.2 in a highly degraded site). We believe that the effect of the environment on the Odonata community structure may be mostly due its effect on Zygoptera and on smaller sized Anisoptera species (e.g. Perithemis, Micrathyria 
and Diastatops), although the determining effect was not strong enough to show significant effects on the Anisoptera suborder. However, Dolný et al. (2012) showed the dependence of Zygoptera on habitat structure and its association to ecosystem characteristics making them specialist organisms and excellent habitat bioindicators. Thus, for some species, the niche conservatism and lack of ability of adapting to environmental changes are the key factors in explaining the loss of genetic variability and the residence of species in the environment (Wiens 2004, Wiens and Graham 2005). These environmental requirements are some of the characteristics that make Odonata sensitive to changes in the environment and thus widely used bioindicators (Dolný et al. 2012). Therefore, we believe that for Zygoptera, dispersal rates followed by colonization events would modify both species abundance (patch - dynamic model) as well as interaction among species (Pulliam 1988 and Leibold et al. 2004).

The distances between the sites sampled in the Suiá-Missú River Basin were not enough to create barriers or obstacles in species distribution. Streams are dendritic systems with imposed restrictions regarding the direction of dispersion by the surrounding terrestrial environment (Fagan 2002). Thus, a population of stream segment is partially isolated from populations of other streams from the river basin. As a consequence of this restriction in the migration direction, population dynamics may be relatively independent. In a stream, a species dynamics may have an increasing trend, while having a decreasing trend (possibly reaching extinction) for other species. We believe that in dendritic systems, ecological processes occur within the individual branches, and the nodes become transfer sites where branch dynamics may be altered when continuing along the network (Campbell et al. 2007), allowing Odonata to disperse throughout the river basin. Thus, this variable did not have a structuring effect on Odonata (and its suborders) composition. Another factor, discussed by McCauley et al. (2008), is that in lentic systems niche and dispersal are factors that affect Odonata larvae spatial distribution processes and species richness.

The connectivity in a river basin may represent access routes to different tributaries, allowing, or functioning, as ecological corridors. Therefore, we assume that the neutral model was not sufficient to represent the processes of Odonata larvae distribution between local sites on a regional scale, or its inter and intraspecific patterns. This result may indicate that for aquatic environments a geographical distance is not quite significant. Thus, as shown by Landeiro et al. (2011), we believe that watercourse distancemay bea better predictor within a spatial scale. The distance between sites did not predict the distribution of the Odonada suborders, even for Zygoptera which have lower dispersal ability and greater ecophysiological requirements (Conrad et al. 1999, Corbet 1999, Needhan et al. 2000 and Conrad et al. 2002). Similar results were found by Juen and De Marco (2011), who reported a lack of influence of spatial scales in Odonata betadiversity. However, the suborder Zygoptera was influenced by the environmental variables. Still, despite Hubbell (2001) proposing that all species have the same competitive ability, dispersal ability and ecosystem adaptation skills, this theory did not support Odonata larvae distribution dynamics in this study.

The environment proved to be the main force structuring the Zygoptera community due to its sensibility and ecological requirements. This community is more influenced by the environment. The Anisoptera suborder was not correlated with any variable, supporting our hypothesis that organisms with higher sensitivity and specificities would be more dependent on the environmental gradient (Niche theory). However, we cannot state that all the Anisoptera suborder consists of generalist individuals. Specific studies may demonstrate that the results could be influenced by the larger number of generalist species. 
It is important to distinguish which factors are more important in structuring a community. That is, if environmental conditions, physical conditions, or solely resource availability will predict species occurrence (Townsend et al. 1987), once all three may be vital for the survival of some species. A more detailed analysis by partitioning the Anisoptera occurrence among conserved and disturbed areas may indicate strategies for environmental evaluation.

The landscape diversity may be determined by the dispersal and ecophysiological ability of individuals to occupy and coexist in different spatial and temporal scales (Hanski and Gilpin 1991, Urban 2004). The implementation of conservation strategies in a river network structure proves to be an effective model for characterizing spatial biodiversity attributes (Muneepeerakul et al. 2008). Site heterogeneity may explain the difference in the structure of the Odonata larvae community based on their interactions and connectivity among water bodies, making it an important control on the dynamics of a metacommunity at the landscape scale. Therefore, we discard the spatial scale (distance between sites) as a limiting factor in Odonata assemblage structure which proved to be mediated by individual adaptations to biotic and abiotic interactions (Urban 2004). In this context, metacommunity may be resistant to disturbance, since heterogeneity and environmental connectivity between patches is maintained (Urban 2004).

\section{ACKNOWLEDGMENTS}

We thank Nelson Silva Pinto for the suggestions, the Laboratory of Entomology (Laboratório de Entomologia) from Nova Xavantina/UNEMAT, and all the staff for their help in field. We also thank Conselho Nacional de Desenvolvimento Científico e Tecnológico (CNPq) for the funding (proc. $\mathrm{n}^{\mathrm{o}} 520268 / 2005-9$ ), FAPEMAT for the Scientific Initiation scholarship granted to the student Thiago Pereira Mendes, which enabled an exclusive dedication to this project, and the partners EMBRAPA, ISA and NGOs related to Y Ikatu Xingu Campaign, which motivated this project. Lastly, we thank the support of PROPESP/UFPA and FADESP for the publication, Federal University of Pará (Universidade Federal do Pará - UFPA), and Graduate Program in Fisheries and Aquatic Ecology (programa de Pós-Graduação em Ecologia Aquática e Pesca - PPGEAP) for the master's scholarship. Leandro Juen is acknowledged by continuous support through $\mathrm{CNPq}$ productivity grants.

\section{RESUMO}

Características ambientais e distâncias espaciais entre os locais foram utilizadas para explicar a distribuição das espécies no ambiente, através das predições da teoria Neutra (espaço) e teoria do Nicho (ambiente). Foram avaliados os efeitos de fatores geográficos e ambientais sobre a distribuição de larvas de Odonata ao longo da Bacia do Rio Suiá-Missu, no estado de Mato Grosso. Nós testamos a hipótese de que (1) o ambiente é o principal fator de estruturação da comunidade devido às suas exigências ecofisiológicas; e (2) o padrão, se presente, é mais expressivo para Zygoptera. As amostras foram feitas em 12 locais na Bacia do Rio Suiá-Missu, em três campanhas (2007/2008), com um total de 1.382 larvas de Odonata, composta por 10 famílias, 51 gêneros e 100 morfoespécies. Os Anisoptera foram mais abundantes que Zygoptera, que compreende $81 \%$ de todas as amostras. $\mathrm{O}$ ambiente afetou Zygoptera $(\mathrm{R}=$ $0,291 ; p=0,007)$ e foi o principal fator de estruturação da assembléia. Assim, a teoria do nicho foi confirmada A ausência deste efeito sobre Anisoptera pode ser devido às adaptações ecofisiológicos que lhes permitem ocupar diferentes habitats. Larvas de Zygoptera são indicadores de mudanças na estrutura do habitat. Os efeitos das variáveis ambientais sobre a ecologia das larvas enfatizam a forte relação entre esses organismos e integridade ambiental.

Palavras-chave: Anisoptera, Zygoptera, teoria neutra, teoria do nicho, Transição Cerrado - Amazônia. 


\section{REFERENCES}

Assis JCF, CARVAlHo AL AND Nessimian JL. 2004. Composição e preferência por microhabitat de imaturos de Odonata (Insecta) em um trecho de baixada do rio Ubatiba, Maricá-RJ, Brasil. Rev Bras Zool 48(2): 273-282.

Borcard D, LEGENDRE P, Avois-JACQUeT C AND TUOMISTO H. 2004. Dissecting the spatial structure of ecological data at multiple scales. Ecology 85: 1826-1832.

BORCARD D AND LEGENDRE P. 2002. All scale spatial analysis of ecological data by means of principal coordinates of neighbor matrices. Ecological Modeling 153: 51-68.

Campbell Grant EH, Lowe WH and Fagan WF. 2007. Living in the branches: population dynamics and ecological processes in dendritic networks. Ecol Lett 10(2): 165-175.

CASE TJ AND GILPIN ME. 1974. Interference competition and niche theory. Proc Nat Acad Sci 71(8): 3073-3077.

Chave J 2004. Neutral theory and community ecology. Ecol Lett 7: 241-253.

CHESSON PL AND WARNER RR. 1981. Environmental variability promotes coexistence in lottery competitive systems. Amer Nat 117: 923-943.

ChOVANEC A AND WARINGer J. 2001. Ecological integrity of river - floodplain systems - assessment by dragonfly surveys (Insecta: Odonata). Regul River 17(4-5): 493-507.

CONRAD KF, Wilson KH, HaRvey IV, Thomas CJ AND SHERRATT TN. 1999. Dispersal characteristics of seven odonate species in an agricultural landscape. Ecography 22: 524-531.

CONRAD KF, WILSON KH, WHITFIELD K, HARVEY IF, THOMAS CJ AND SHERRAT TN. 2002. Characteristics of dispersing Ischnura elegans and Coenagrion puella (Odonata): age, sex, size, morph and ectoparasitism. Ecography 25(4): 439-445.

CorBet PS. 1962. A biology of dragonflies. London, Witherby, $247 \mathrm{p}$.

CoRBET PS. 1999. Dragonflies: behavior and ecology of Odonata. Ithaca: Comstock Publ. Assoc., 829 p.

CordobA-Aguilar A. 2008. Dragonflies and Damselflies. Model organisms for ecological and evolutionary research. Oxford University Press, Oxford, UK, 290 p.

Costa JM, De Souza LOI And Oldrini BB. 2004. Chave para identificação para as famílias e gêneros das larvas conhecidas para o Brasil: Comentários e registros bibliográficos (Insecta; Odonata). Publicações Avulsas do Museu Nacional, Rio de Janeiro 99: 1-44.

De Marco Jr P And Latini AO. 1998. Estrutura de Guildas e riqueza de espécies em uma comunidade de larvas de Anisoptera (Odonata), p. 101-112. In: JL Nessimian e Carvalho AL (Eds), Ecologia de Insetos Aquáticos. Séries Oecologia Brasiliensis Vol. 5. Rio de Janeiro, PPGEUFRJ, xvii + 309 p.

DE MARCO Jr P AND Vianna DM. 2005. Distribuição do esforço de coleta de Odonata no Brasil: subsídios para escolha de áreas prioritárias para levantamentos faunísticos. Lundiana 6: 13-26.
DINIZ-FILHO JAF AND BINI LM. 2005. Modelling geographical patterns in species richness using eigenvector based spatial filters. Global Ecol Biogeogr 14:177-185.

Diniz-FILHO JAF, OLIVEIRA LG AND Silva MM. 1998. Explaining the beta diversity of aquatic insects in "Cerrado" streams from central Brazil using multiple Mantel test. Rev Brasil Biol 58(2): 223-231.

DOLNÝ A, HARABIŠ F, BÁRTA D, LHOTA S AND DROZD P. 2012. Aquatic insects indicate terrestrial habitat degradation: changes in taxonomical structure and functional diversity of dragonflies in tropical rainforest of East Kalimantan. Trop Zool 25(3): 141-157.

Dray S, Legendre P AND Peres-Neto PR. 2006. Spatial modeling: a comprehensive framework for principal coordinate analysis of neighbor matrices (PCNM). Ecological Modeling 196: 483-493.

FAGAN WF. 2002. Connectivity, fragmentation, and extinction risk in dendritic metapopulations. Ecology 83: 3243-3249.

FERREIRA-PERUQUetTI P AND DE MARCO Jr P. 2002. Efeito da alteração ambiental sobre comunidades de Odonata em riachos de Mata Atlântica de Minas Gerais, Brasil. Rev Bras Zool 19: 317-327.

GRIFFITH DA AND PERES-NeTo PR. 2006. Spatial modeling in Ecology: the flexibility ofeigenfunction spatial analyses. Ecology 87: 2603-2613.

HALLGRIMSSON B AND MAIORANA V. 2000. Variability and size in mammals and birds. Biol J Linn Soc 70(4): 571-595.

HANSKI I AND GILPIN M. 1991. Metapopulation dynamics: brief history and conceptual domain. Biol J Linn Soc 42(1-2): 3-16.

HARVEY IF AND CORBET PS. 1985. Territorial behaviour of larvae enhances mating success of male dragonflies. Anim Behav 33: 561-565.

HaYes FE AND SEwlal JD. 2004. The Amazon River as a dispersal barrier to passerine birds: effects of river width, habitat and taxonomy. J Biogeogr 31: 1809-1818.

HECKMAN CW. 2006. Encyclopedia of South American aquatic insects: Odonata - Anisoptera. Springer, 725 p.

HEINRICH B. 1993. The hot-blooded insects: strategies and mechanisms of thermoregulation. Cambridge, Massachusetts, Harvard University Press, 601 p.

HEINRICH B AND CASEY TM. 1978. Heat transfer in dragonflies: 'fliers and perchers'. J Exp Biol 74: 17-36.

HeISER M AND SCHMITT T. 2010. Do different dispersal capacities influence the biogeography of the western Palearctic dragonflies (Odonata)? Biol J Linn Soc 99(1): 177-195.

HubBELl SP. 2001. A Unified Neutral Theory of Biodiversity and Biogeography. Princeton University Press, Princeton, NJ, $390 \mathrm{p}$.

Hughes TP, Baird AH, Dinsdale EA, Mollschaniwskyj NA, PRATChetT MS, TANNER JE AND WiLlis BL. 2000. Supply-side ecology works both ways: The link between benthic adults, fecundity and larval recruits. Ecology 81(8): 2241-2249. 
JANKOWSKI JE, CIECKA AL, MEYER NY AND RABENOLD KN. 2009. Beta diversity along environmental gradients: implications of habitat specialization in tropical montane landscapes. J Animal Ecol 78: 315-327.

Juen L, Cabette HSR And De Marco Jr P. 2007. Odonate assemblage structure in relation to basin and aquatic hábitat structure in Pantanal wetlands. Hydrobiol 579: 125-134.

Juen L AND De Marco Jr P. 2011. Odonate biodiversity in terra-firme forest streamlets in Central Amazonia: on the relative effects of neutral and niche drivers at small geographical extents. Insect Conserv Divers 4(4): 265-274.

Juen L AND De Marco Jr P. 2012. Dragonfly endemism in the Brazilian Amazon: competing hypotheses for biogeographical patterns. Biodivers Conserv 21: 3507-3521.

LANDEIRO VL, MAGNUSSON WE, MELO AS, EsPíRITO-SANTO HMV AND BINI LM. 2011. Spatial eigenfunction analyses in stream networks: do watercourse and overland distances produce different results? Freshwater Biol 56(6): 1184-1192.

LEGENDRE P AND LEGENDRE L. 1998. Numerical ecology. Elsevier, Amsterdam, $870 \mathrm{p}$.

Leibold MA, Holyoak M, Mouquet N, Amarasekare P, Chase JM, Hoopes MF AND GonZALEZ A. 2004. The metacommunity concept: a framework for multi-scale community ecology. Ecol Lett 77: 601-613.

MAY ML. 1976. Thermoregulation in adaptation to temperature in dragonflies (Odonata: Anisoptera). Ecological Monographs 46(1): 1-32.

MAY ML. 1991. Thermal adaptations of dragonflies, revisited. Advances in Odonatology 5: 71-88.

McCauley SJ, Davis CJ, Relyea RA, Yurewicz KL, SKelly DK AND WERNER EE. 2008. Metacommunity patterns in larval odonates. Oecologia 158: 329-342.

MoORE AJ. 1987. Behavioral ecology of Libellula luctuosa (Burmeister) (Anisoptera: Libellulidae). 2. Proposed functions for territorial behaviors. Odonatologica 16: 385-391.

Muneepeerakul R, Bertuzzo E, Lynch HJ, Fagan WF, RINALDO A AND RODRIGUEZ-ITURBE I. 2008. Neutral metacommunity models predict fish diversity patterns in Mississippi-Missouri basin. Nature 453(7192): 220-222.

NeEdham JG, Westfall Jr MJ AND MAY ML. 2000. Dragonflies of North America No. Rev. Ed. Scientific Publishers Inc., 940 p.

Peres-Neto PR, LEGENDRE P, DRAY S AND BorCARD D. 2006 Variation Partitioning of Species Data Matrices Estimation and Comparison of Fractions. Ecology 87: 2614-2625.

PETERS RH. 1987. The Ecological Implications of Body Size. Cambridge University Press, 329 p.

PoFF NL. 1997. Landscape filters and species traits: towards a mechanistic understanding and prediction in stream ecology. J North Am Benthol Soc 16: 391-409.
Pontin AJ. 1982. Competition and Coexistence of Species. Pitman, London, 102 p.

PULLIAM HR. 1988. Sources, sinks, and population regulation. Am Nat 132: 652-661.

RANGEl TF, DINIZ-FILHo JAF AND BINI LM. 2010. SAM: a comprehensive application for Spatial Analysis in Macroecology. Ecography 33: 46-50.

RATTER JA, ASKEW GP, MONTGOMERY RF AND GIFFORD DR. 1978. Observations on the vegetation of northeastern MatoGrosso II. Foreste Soils of the Rio Suiá - Missú rea. R Soc Lond Serie B Biol Sci 203(1151): 191-208.

R Development Core TEAM. 2010. R: A language and environment for statistical computing. R Foundation for Statistical Computing, Vienna.

RICKLEFS RE. 1987. Community Diversity: Relative Roles of Local and Regional Processes. Science New Series 235(4785): 167-171.

SCARANO FR AND DiAS ATC. 2004. A Importância de Espécies no funcionamento de comunidades e ecossistemas. In: Ecologia Teórica: desafios para o aperfeiçoamento da Ecologia no Brasil. Coelho AS, Loyola RD, Souza MBG (Eds), Belo Horizonte: Ed. O Lutador, 122 p.

TANIGUCHI H AND TOKESHI M. 2004. Effects of habitat complexity on benthic assemblages in a variable environment. Freshwater Biol 49(9): 1164-1178.

Thomaz SM, DibBle E, Evangelista LR, Higuti J AND BINI LM. 2008. Influence of aquatic macrophyte habitat complexity on invertebrate abundance and richness in tropical lagoons. Freshwater Biol 53(2): 358-367.

THOMPSON DJ. 1987. Regulation of damselfly populations: The effects of weed density on larval mortality due to predation. Freshwater Biology 17: 367-371.

TOWNSEND CR, HiLdREW AG AND SCHOFIEld K. 1987. Persistence of Stream Invertebrate Communities in Relation to Environmental Variability. J Anim Ecol 56(2): 597-613.

TSCharntKe T, STEFFAN-DEWENTER I, KRUESS A AND THIES C. 2002. Contribution of small habitat fragments to conservation of insect communities of grassland-cropland landscapes. Ecol Appl 12(2): 354-363.

URBAN MC. 2004. Disturbance heterogeneity determines freshwater metacommunity structure. Ecology 85(11): 2971-2978.

WIENS JJ AND GRAHAM CH. 2005. Niche conservatism: integrating evolution, ecology, and conservation biology. Ann Rev Ecology Evol System 36: 519-539.

WIENS JJ. 2004. Speciation and ecology revisited: phylogenetic niche conservatism and the origin of species. Evolution 58: 193-197. 